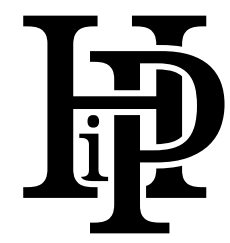

Historia i Polityka

No. 36(43)/2021, pp. 139-151

www.hip.umk.pl @® $\Theta$

ISSN 1899-5160, e-ISSN 2391-7652

DOI: http://dx.doi.org/10.12775/HiP.2021.018

Mariusz JANIK

Polish Academy of Sciences, Institute of Economics, Warszawa, Poland

\title{
Economic and Political Reconstruction and Development of FRG in the Period after World War II
}

\author{
Odbudowa potencjału gospodarczo-politycznego i rozwój RFN \\ w okresie po II wojnie światowej
}

\section{- Abstract •}

In the first post-war years, the policy of the Western occupying powers towards Germany was aimed at preventing the economic revival of their former formidable competitor. As a result of these efforts, West Germany rebuilt its economy to the pre-war level later than Great Britain or France. The undoubted shift in the economic development of West Germany began in mid-1948. The impetus for the rapid growth of industrial production was the monetary reform carried out by the Western occupying powers, as well as the inflow of funds under the Marshall Plan. The monetary reform carried out in June 1948 favored the strengthening of the financial market and was an incentive to invest. The influx of capital under the Marshall Plan had a similar impact on the West Germany's economy during this period. The western zones of Germany played a special role in this plan. The United States, striving to strengthen its position in these zones as much as possible and use them as a strategic base (aimed, inter alia, against the communist bloc), provided West Germany with a sum of loans and

\section{- Abstrakt •}

W pierwszych latach powojennych polityka zachodnich mocarstw okupacyjnych względem Niemiec nakierowana była na zapobieganie ekonomicznemu odrodzeniu się ich dotychczasowego groźnego konkurenta. W wyniku tych zabiegów Niemcy Zachodnie odbudowały swoją gospodarkę do poziomu przedwojennego później niż Wielka Brytania czy Francja. Niewątpliwy zwrot w dziedzinie rozwoju ekonomicznego Niemiec Zachodnich rozpoczął się w połowie 1948 r. Impulsem pobudzającym szybki wzrost produkcji przemysłowej była przeprowadzona przez zachodnie mocarstwa okupacyjne reforma monetarna, jak również napływ środków finansowych w ramach planu Marshalla. Przeprowadzona w czerwcu 1948 r. reforma monetarna sprzyjała wzmocnieniu rynku finansowego i stanowiła bodziec do inwestowania. Podobny wpływ na gospodarkę zachodnioniemiecką w tym okresie wywarł napływ kapitałów w ramach planu Marshalla. W planie tym zachodnie strefy Niemiec odgrywały szczególną rolę. Stany Zjednoczone, dążąc do maksymalnego wzmocnienia swojej pozycji w tych strefach i wy- 
subsidies significantly exceeding the amount of aid provided to other Western European countries. An extremely serious burden for the Western occupation zones was the influx of refugees from neighboring areas (a total of about 10 million people) and the need to maintain the occupation troops, which directly led to a huge deficit in food resources. Agricultural production fell and ranged only from $66 \%$ to $75 \%$ of the pre-war production level.

Keywords: FRG; occupation zones; "economic miracle"; industry and agriculture; Erhard's reform; economic growth and development; social market economy; Marshall Plan; economic fluctuations korzystania ich jako bazy strategicznej (wymierzonej m.in. przeciwko blokowi komunistycznemu), przekazały Niemcom Zachodnim sumę kredytów i subsydiów znacznie przewyższającą wielkość pomocy dla pozostałych krajów Europy Zachodniej. Niezwykle poważnym obciążeniem dla zachodnich stref okupacyjnych był napływ uchodźców z sąsiednich terenów (łącznie ok. $10 \mathrm{mln}$ osób) oraz konieczność utrzymania okupacyjnych wojsk, co bezpośrednio prowadziło do ogromnego deficytu w zasobach żywności. Produkcja rolna spadła i kształtowała się tylko w przedziale od $66 \%$ do $75 \%$ poziomu produkcji przedwojennej.

Słowa kluczowe: RFN; strefy okupacyjne; „cud gospodarczy"; przemysł i rolnictwo; reforma Erharda; wzrost i rozwój gospodarczy; społeczna gospodarka rynkowa; plan Marshalla; wahania koniunkturalne

Once the World War II was over, the economic policy of the Allies occupying the three Western zones of Germany (American, British, and French) not only did not aim to rebuild the economic potential of this part of Germany, but on the contrary, pursued a plan to deindustrialize the country so that the reduction of production capacity would bring it to the level of $50-55 \%$ of that in 1938 . The Allies banned the production of armaments, seagoing ships, aircraft, synthetic gasoline, and other products (Gedymin, 1999, p. 62). A significant burden on the Western occupation zones represented the influx of refugees and displaced persons from Poland, Czechoslovakia, and the East German territories. Approximately 10 million people arrived in the western occupation zones. Already before World War II, Germany was a food importer, and the then domestic production of meat and fats covered only $50-60 \%$ of its requirements.

The collapse of money (Reichsmark) market was the result not only of shortages of consumer goods but also of other processes. During the war, price controls had successfully prevented price hikes, but after the war a gap began to grow between the still-frozen prices of the means of production and the rapidly rising costs of production. This increase was caused, on the one hand, by a falling labour productivity (by about $50 \%$ compared with the pre-war period), and on the other hand, technical wear and tear of machinery and equipment due to insufficient repair and modernization efforts. The continuation of the system of administrative distribu- 
tion of materials and raw materials, as well as machine parts, with their acute shortage, led to the emergence of a "black market" also in this area, which manifested itself, inter alia, in the occurrence of barter trade, settled, however, at the official prices (Abelshauser, 2004, pp. 140-162).

Following the defeat of the Third Reich, Germany lost much of its former territory. The area of West Germany after World War II, which was the result of dividing the country by the Allies, accounted only for $53 \%$ of the territory the Germany had occupied before World War II, or more accurately, of the territory with the borders as of 1937. The division of Germany into occupation zones meant that the traditional division of labour between the western and eastern regions of the country was disrupted. This required the establishment in West Germany of the foundations for several important manufacturing industries, the entire infrastructure of which was located in East Germany. The losses suffered by heavy industry during the war and subsequently, as a result of dismantling, were estimated at 18.2 per cent of the global share capital. A year after the Nazi Germany signed its capitulation treaty, the West Germany's industrial output accounted only for $1 / 3$ of that from before the war. In practice, basic and fundamental industries for the economy ceased to exist. It is important to emphasize that the production assets that were located on the territory of West Germany were much larger in 1948 than before the war conflict began (Erhard, 2012). This was due to the fact that practically until the last day of the war, the Third Reich was expanding its factories, plants and all related infrastructure (Błahut, 1992).

In 1944, when Hitler's Germany was in a difficult position and everything seemed to indicate that it would soon lose the war, investments were still being made in the economy that were far in excess of total depreciation. When the West Germany's economy began to grow, it had at its disposal an efficient and enormous, and most importantly, modern manufacturing assets. More than $11 \%$ of its total consisted of equipment that was less than five years old. In contrast, machinery that was no more than 10 years old accounted for about $34 \%$ of the total manufacturing assets. Of great importance for West Germany was the fact that it included the Ruhr Area (Ruhrgebiet), which was of great strategic importance from the economic point of view. With it, the West German economy received heavy industry, which was the foundation of all German industry. Other major industrial centers were also located there. As a result of the reforms and the economic policy pursued, industrial production and exports grew rapidly.

Immediately after the end of the conflict, which ultimately led to Germany's defeat both in military and political terms, the country had practically no conditions not only conducive to, but at all enabling the development of an economy 
based on the division of labour. The devastation caused by the war and the loss of skilled human resources that left the country put West Germany in a situation where the lack of serious and profound reforms would lead to the country having no chance of regaining its former position as one of the strongest in the world.

During the first years after the war, the occupying authorities pursued a restrictive policy towards West Germany, which was eventually abandoned because they concluded that the stabilization of the European economy depended to a large extent on the state of the German economy and the country position as a whole. It should be added that political considerations were also taken into account, which assumed that West Germany represented a border and a protective barrier for the entire Western part of Europe, which protected it from the Sovietization carried out by the Soviet Union in its satellite countries (including but not limited to Poland, Czechoslovakia, and Hungary), and which the Soviet Union wanted to expand also to the other parts of the continent, which was prevented by, inter alia, the division of Germany. An important fact for the country was that after a devastating war lasting several years, Germany began to rebuild its economy with a capital that exceeded the pre-war level. This was mainly due to the changes in the Germany's potential and economic structure in the run-up period and during the war.

An extremely heavy burden for the Western occupation zones was the influx of refugees from neighboring areas (a total of about 10 million people) and the need to maintain the occupying army, which directly led to a huge deficit in food supplies. Agricultural production declined and was only between $66 \%$ and $75 \%$ of pre-war production levels. This resulted in malnutrition, enhanced sickness rate, family separations, and general insecurity. In addition, stress levels mounted and the physical fitness of the population declined. This led to some individuals being forced to try to be self-sufficient, so the crops necessary for survival were produced and grown on their own.

The reconstruction of the Federal Republic of Germany after World War II has been called the "German economic miracle". Its success was largely due to Professor Ludwig Erhard, who, first as an advisor to the occupation authorities and then as the Minister of Finance, Vice Chancellor and finally Chancellor of the FRG, assured that the German economy had the right environment for development (Lewandowski, 1991). Erhard did not like the term "economic miracle". Whenever he had an opportunity, he explained that there was no miracle, but such effects were the result of taking well thought out decisions and translating them into practical actions. The free market economy had to bring development and prosperity to Germany (Moszyński, 2012). Erhard introduced it against the will of the citizens and against the laws in force at the time, as well as against (what was most difficult) the 
Allied authorities of the time. Ludwig Erhard is primarily associated with the currency and price reform of 1948, while less is written about his activities as the leader of the economic team that programmed in stages and directed the transformation of the German economy after the 1948 reform: a structure then deformed by command-and-control methods of central management that suspended the price mechanism in many sectors (Gedymin, 2002, p. 261).

The economy, which was based on market and private ownership, was also very successful in a country that was devastated on many levels. Importantly, the society was a demographically completely shattered structure (primarily because most young Germans of working age died during the war). Despite the large numbers of dead and missing (both about 3.5 million), the population remained unchanged compared to 1938 and was about 10 million people (even the strong wave of refugees did not change that). In addition, the mental health of the population was badly damaged, caused by the defeat suffered, and the coming round to realize the bestiality to which the German people had gone during the war. It should be noted that the Marshall Plan which was a great help in recovery of the German economy, but while it was a valuable cash injection, it was not without its problems.

Very often, financial aid was not used properly, and what is more, huge sums of money were stolen by influential people. The American aid was not at all a prerequisite for recovery and, moreover, it was not necessary, despite many opinions still claiming the opposite. The political situation in the entire Europe was of great significance. At the same time, socialists and often communists were gaining popularity in France, Italy, and Great Britain. In the case of Germany, Konrad Adenauer was elected first as chancellor and then he was followed by Ludwig Erhard (Thieme, 1995, p. 24).

In 1947, the aforementioned Marshall Plan was enacted, the implementation of which would be jeopardized by the protracted post-war instability. Meanwhile, the Western occupiers were already interested in reforming and rebuilding the German economy, to which the main stream of aid under the plan was to flow. Indeed, the occupation authorities developed the reform underlying assumptions jointly with Erhard, and some analysts believe that the opinions of the occupiers (primarily the Americans) were more important than those of Erhard himself and his associates.

The Marshall Plan was announced in June 1947 by the U.S. Secretary of State A. Marshall (Cowen, 1985). He announced the participation of the United States in the reconstruction of the economies of European countries on the condition that the governments of these countries submit appropriate plans for the utilization of American funds. The implementation of the European Recovery Program (ERP), commonly referred to as the Marshall Plan, began in July 1948 and was completed 
in late 1954. The total amount of American aid under this plan was 16.400 million USD, of which West Germany received aid worth (according to various estimates) 1.5-2 billion USD. On a per capita basis, this amount was in the range of thirty-some dollars (for France and Great Britain it was \$74 and \$71, respectively). The main portion of the aid focused on the supply of scarce goods and raw materials on the basis of a long-term loan. In addition, some of the supplies were treated as non-refundable aid.

After the end of war, the Allies arbitrarily fixed the rate of the mark to the dollar: 10 cents per mark (Reichsmark - RM). This exchange rate had no economic relationship between intra-German and global prices. Just before the currency reform of 1948, the US Bi-zone administration had introduced a rate of 30 cents per $1 \mathrm{RM}$ and this rate was maintained after the reform with respect to the Deutsche Mark, although special rates were applied to certain raw materials. Independent rates were established for the British and French currencies. When the Federal Republic of Germany was formed in autumn 1949 as a result of merging all occupation zones, the rate was set at 0.238 USD for $1 \mathrm{DM}$. Full convertibility of the currency was introduced only in the second half of the 1950s (in 1958) (Kowalik, 1999, pp. 64-69).

The state of the economy at that time prior to the reform is illustrated by many facts. In the Bi-zone, i.e., in the British-American zone (the 1948 reform was limited in the first phase to the Bi-zone), prices of the vast majority of consumer and manufactured goods were regulated, deviating strongly from the black market prices. According to T. Kowalik, "not so much open inflation as suspended inflation took place. The official cost of living index in the American occupation zone from October 1945 to May 1948 rose only by 17\%” (Kowalik, 2005, pp. 59-70). German currency, however, was very weak due to the vast range of the black market. Barter and black market exchanges reached half of industrial products. American cigarettes or coffee were often used as a means of exchange and hoarding. Black market prices were often 50 or even 200 times higher than official prices. This must have resulted in "hoarding", i.e., collecting reserves, the disappearance of industrial output and its almost symbolic share in exports. This is also indicated by the enormous monetary overhang (Kowalik, 2000, pp. 69-83).

The so-called economic miracle began with currency reform. On June 21, 1948, a new currency was put into circulation in the Western occupation zones, which took the name of Deutsche Mark and became a symbol of strong money and stable economy. What is important, for many years no one tried to manipulate its exchange rate, which allowed some people to make money, but in effect led more than once to many serious and negative consequences (Deutsches Geld..., 1977). 
The German Federal Bank (Deutsche Bundesbank) was established, which was partly independent from the government. It exercised control over the budget and did not allow politicians to influence it more than was reasonable. Although the discount rate was manipulated, as were the mandatory bank reserves, and openmarket operations were carried out, these were done to stabilize a currency that was subject to fluctuations. It did not affect the business cycle itself or its course but only the currency.

In parallel to the currency reform, even before the reunification of the Western occupation zones in June 1948, the Provisional Economic Administration headed by Erhard decided that its (the Administration's) powers would be subject to selfrestraint, which would have a beneficial effect on market mechanisms. In addition, the area of rationing was reduced, especially with regard to prices. This was a good move, because as experience shows (e.g., in Poland, where many years after the transformation such an option was not used), interfering with the price mechanism is not always a good solution and often brings severe losses.

Putting into order of ownership relations was of strategic significance. Therefore, an attempt was made to use the currency reform for this purpose. It was not a simple process of money exchange. Stocks and physical assets were valued at a 1:1 ratio, but cash and bank deposits were valued at a 10:1 ratio, while other monetary claims were valued at up to 15:1 ratio. The tax system did not affect the process of capital accumulation and investment, and consumption was taxed more heavily. This made it possible to strengthen small businesses, which took on the burden of rebuilding the German economy. At the same time, they were able to earn more than before, which they used well. Also, the middle class, which had initially struggled with many problems immediately after the war, grew in strength.

An important step in the history of the Federal Republic of Germany was the passing of a law against the restriction of competition by the Bundestag on July 27, 1957, which was called the "Great Charter of the Social Market Economy". It outlawed all agreements that influenced production or market relations in the marketing of goods or services by restricting competition (Gruenig \& Krengel, 1955). A Federal Cartel Office was established, which, among its powers, even had the authority to prohibit the activities of a particular company or association, whenever such activities were deemed to be contrary to the principles of the market-driven economy (Wielka historia świata, 2006, p. 172).

Erhard perceived a tremendous opportunity in linking monetary reform with the measures that brought a well-deserved end to the administrative economy and put an end to the ill-advised drive to introduce it in the future. In this case, the now former German chancellor (who died in 1977) was wrong. His reforms did 
not make, as he put it, "unreasonable administrative pursuits" disappear. The great reformer did not foresee, however, that in every country there are and will be politicians who promise their voters more than they can deliver, inter alia, by saying that it is enough to vote for a given candidate to earn more money while working less.

The German economic miracle was referred to by the Germans themselves as the "Wirtschaftswunder". This term was used to describe the operation that Finance Minister L. Erhard carried out in the German economy during several weeks in 1948. The operation consisted of several measures, which included:

- monetary reform (the goal was to eliminate inflation by reducing the money supply by as much as $93 \%$ and to restore the value of the new German mark-DM),

- price liberalization (this was supposed to make prices more flexible and bring the economy out of recession),

- tax reform (Wielka historia świata, 2006, p. 172).

As a result of the above measures, the mood in the country changed dramatically. Poverty was gradually eradicated, industrial production started to grow (by as much as $50 \%$ in only six months), and imports and exports increased. Germany also benefited from financial aid, which was provided for under the Marshall Plan, however, the value of the funds that the country received under this plan was not more than $5 \%$ of the then national income, which amounted to 1.448 million US dollars. A significant influence on such a rapid improvement in the situation of the economy was also the fact that Germany was burdened with very low war reparations. Their amount was indirectly influenced by the experience gained after World War I.

With the introduction of monetary reform on June 20, 1948, the prices of numerous goods and services were freed up, especially in those industries where administrative price control was very difficult and price increases had little impact on the cost of living, while further government regulation of prices affected a vast sector of enterprises (private and public) in the sectors of manufacturing and services. Thus, the government continued to control wages, food prices and rental fees, public services, tickets for urban and intercity transportation, railroad and freight tariffs, as well as the prices of steel, coal, oil, and some non-ferrous metals, as well as the prices of securities. International trade was also rationed by state agencies. The government published periodically mandated and specified price levels, generally stating maximum price ceilings, determined in consultation with representatives of industry, commerce, and labour unions.

The derationing of individual markets was timed so as not to have a shock impact on working family budgets and the functioning of enterprises. First, after al- 
most 6 months after the currency reform, the wage freeze was lifted up and freedom of tariff negotiations was restored. Derationing of the food market took about a year and a half, and rental fees took as long as 11 years. It was not until more than 14 years after the currency reform that free market steel prices were introduced, however, coal prices remained under government control (Wallich, 1955).

The 1948 currency reform was the first link in the government's long-term strategy to develop and strengthen market mechanisms, and the financial sector of the economy occupied a special place in this strategy. The strategy consisted of two main phases: the first phase referred indicatively to the first three years after the currency reform, when the self-financing of corporate investments (with generated profits, depreciation and short-term bank loans) amounting in the first year after June 1948 to $0-74.7 \%$ fell in 1950 to $39 \%$ of total capital expenditures, and the share of capital market funds rose from $6.7 \%$ to $17.8 \%$, with the share of public sector funds in financing total capital expenditures going up from $17.1 \%$ to $25 \%$ during this period. The implementation of the 1948 currency reform was itself a disincentive to long-term saving and therefore a restraint on the development of the capital market, but the resources necessary for the self-financing of enterprises were sufficiently large to enable output and national income to rise after the currency reform, in addition to government investment aid.

The government team was aware that the structure of capital sources, in which self-financing of enterprises prevailed, was disadvantageous in the long run due to the underdevelopment of market mechanisms for allocating investment funds across the economy. It was about greater incentive and freedom of investment funds flow to enterprises and industries characterized by the highest expected profitability in the long run. From a macroeconomic perspective, it was the developed capital market that enabled businessmen to take into account the opportunity costs of investing, shaped by financial markets and integrated with the entire economy (Bossak, 2008). In the initial period after the implementation of currency reform, effective demand was so strong that almost every investment in the consumer goods sector was characterized by high profitability, but as production capacity was going up, the competitive struggle in numerous markets intensified and profit margins gradually declined.

The development of the capital market in Germany was moving towards a market-driven model where financial agency services were (and still are) mainly based on banks. Under such system, the capital market not only provides information on ROIs in individual industries and on the cost of capital, but also promotes the participation of bank representatives in making investment decisions in enterprises and determining the capital structure of enterprises, since banks are interested in 
such a selection of investment projects that would guarantee servicing and repayment of extended loans. According to O. Gedymin (Gedymin, 2002), the characteristic features of the period of intensive modernization in Germany in the dozen or so years after the introduction of the currency and price reform were:

- rapid growth (additionally stable) of the country's GDP (in some periods even surpluses appeared), paralleled by a gradually falling unemployment rate and very low inflation,

- at least balanced (and in some periods showing surpluses) budget of the public sector,

- predominantly undervalued exchange rate of the Deutsche Mark, which was very conducive to export expansion,

- intensive investment of enterprises and public institutions in the development of human capital - particular attention was paid here to professional training of those already working,

- export expansion accompanied by strong protectionism,

- high average saving and investment rates over the long term,

- balance of payments generally positive,

- substantial public subsidization of research and sectoral policies,

- strict observance of the rules of macroeconomic stabilization and independence of the Central Bank from the government,

- corporate structures that complement the activities of parliamentary democratic institutions.

The period from 1953 to 1958 is called the "Golden Years" of the post-war period. By the end of this period, most of the war damage had been removed, a period of dynamic economic growth was underway, a state of full employment had been achieved, and the standard of living of the population had been raised well above the pre-war level. Exports also developed exceptionally well. With a share of $9.2 \mathrm{per}$ cent in world trade, Germany caught up with Great Britain in this respect. In 1958, Germany also made its currency fully convertible. Already at that time Germany saw itself as a fully accepted member of the European Economic Community.

On the other hand, from the perspective of contemporary historians and economists, the "Golden Years" are also the time of the "naïve" phase of economic policy development pursued since the beginning of West Germany (Wagner, 1972). The primacy of economic growth as the main goal of economic policy was maintained, inter alia, thanks to favorable external environment, until it clashed with other set goals and parameters, namely until the gross social product grew at a rapid pace. As K. Grimm (1992, p. 53) argues, it can be said that during this period: 
- the economic fluctuations observed until 1958 were only minor fluctuations on a growth curve that had been rising steadily throughout this period,

- the fluctuations in prices and employment during the period of construction of the social market economy did not come,

- in the period during which the social market economy was being built it did not lead to the conflict of objectives specific to the later period,

- the negative impact of external relations remained unknown until 1958, and was balanced by a positive balance of payments in the range of DM 6 billion.

The decade between 1958 and 1968 was characterized by full employment, fluctuating growth (which was, however, consistently positive), and - apart from some minor fluctuations - a relatively stable price level. In addition, this period saw the first experiences with the introduction of currency convertibility at fixed exchange rates. Just over two cycles fall into this period. The business cycle was determined primarily by changes in the level of investment and the balance of payments. Unemployment did not develop in parallel with the cycle. It was not until the 1967 recession that unemployment went up to $3.2 \%$ in January 1968. Overall, unemployment remained below $1 \%$ throughout the period in question, so from an overall economic perspective one could speak of "over-employment". The structural unemployment of the post-war period was already overcome in the economic boom period from 1959 to 1960 and this despite the influx of refugees on the German labour market until the construction of the Berlin Wall in 1961. From the beginning of the 1960s onward, foreigners were increasingly involved in the labour process.

Although price increases in the 1960 decade remained within certain limits compared to later years, once full employment was reached, prices increased with each successive cycle. While prices rose relatively little in the 1967 crisis year, this was at the expense of stagnation of generated national income (Wawro, 2012). The rise in prices occurred as a result of several factors, including changes in the investment rate and current account balance, as well as wages. Retrospectively, it can be generally said about the decade following 1958 that prices were stable when the rate of wage growth matched the progress of productivity (in constant prices) or when productivity, combined with an increase of the investment rate and a positive current account balance, outpaced wage growth. This happened in 1959, 1967, and 1968.

After the worst downturn in German history, the economy grew rapidly in 1968. Strong demand for export goods, government stimulus programs, a growing willingness to invest, and other factors strengthened the growth phase of Germany's fifth business cycle since the war. Unemployment fell to $1.5 \%$, wages rose moderately, and labour productivity increased rapidly. The federal government gave it- 
self credit for claiming that its stabilization program was bearing fruit and that the newly implemented legal grounds for economic stabilization proved to be effective.

Erhard had erroneously assumed that the concept of a "social market economy" was a panacea for the business cycle phenomenon (Kaczmarek \& Pysz, 2004). Statistical data proves, however, that even after 1966 the declared goal of consolidating overall economic development was not achieved according to the list of goals included in the Stabilization Act of that year. Despite a developed set of purposespecific instruments, the desired goal of economy-wide balance was not approached in subsequent years.

As late as in its 1969 report on economy condition, the federal government assumed the success of its plans to consolidate the economic revival that had been watched since 1967 so that it would take the form of "a relatively steady increase in demand harmonized with the further development of production capacity" (Grimm, 1992, p. 61). In fact, this recovery turned into a period of economic boom followed by a downturn in the spring of 1970, and the turn of 1971-1972 marked the beginning of another recovery, which was sixth post-war business cycle. As the recovery accelerated further during 1973, upward price movement followed soon. This forced the Federal Bank and the government to take steps to stabilize the economy. The first signs of success in this course were thwarted by some missteps on the part of both institutions, and by the global economic recession triggered by the oil shock of mid-1974. This decline was much steeper and more dangerous than the 1967 recession.

\section{References:}

Abelshauser, W. (2004). Deutsche Wirtschaftsgeschichte seit 1945. Bonn: Bundeszentrale für politische Bildung.

Błahut, K. (1992). Elementy polityki gospodarczej Niemiec. Wrocław: Wydawnictwo Uniwersytetu Wrocławskiego.

Bossak, J. (2008). Instytucje, rynki i konkurencja we wspótczesnym świecie. Warszawa: Szkoła Główna Handlowa.

Cameron, R., \& Neal, L. (2010). Historia gospodarcza świata. Od paleolitu do czasów najnowszych. Wrocław: Książka i Wiedza.

Cowen, T. (1985). The Marshall Plan: Myths and Realities. In: D. Bandow (Ed.). U.S. Aid to the Developing World: A Free Market Agenda (pp. 61-74). Washington: Heritage Foundation.

Deutsches Geld-und Bankwesen in Zablen, 1876-1975 (1977). Frankfurt/Main: Deutsche Bundesbank.

Erhard, L. (2012). Dobrobyt dla wszystkich. Warszawa: Polskie Towarzystwo Ekonomiczne. 
Gedymin, O. (1999). Strategie gospodarcze i drogi rozwoju. II Rzeczpospolita, powojenne Niemcy, Tajwan, Chile. Białystok: Wyższa Szkoła Finansów i Zarządzania w Białymstoku.

Gedymin, O. (2002). Kapitalizm niemiecki. Szkice o genezie, rozwoju i teraźniejszości. Białystok: Wyższa Szkoła Finansów i Zarządzania w Białymstoku.

Grimm, K. (1992). Socjalna gospodarka rynkowa w RFN. Koncepcja, rozwój, problematyka. Warszawa: Fundacja im. Friedricha Eberta.

Gruenig, F., \& Krengel, R. (1955). Die Expansion der westdeutschen Industrie 1948-1954. West Berlin: Duncker \& Humbolt.

Kaczmarek, T., \& Pysz, P. (2004). Ludwig Erhard i spoteczna gospodarka rynkowa. Warszawa: ISP PAN.

Kowalik, T. (2000). Wspótczesne systemy ekonomiczne. Powstawanie, ewolucja, kryzys. Warszawa: Wydawnictwo Wyższej Szkoły Przedsiębiorczości i Zarządzania im. Leona Koźmińskiego.

Kowalik, T. (2005). Systemy gospodarcze. Efekty i defekty reform i zmian ustrojowych. Warszawa: Fundacja Innowacja.

Lewandowski, J. (1991). Neoliberatowie wobec wspótczesności. Gdynia: Atext.

Moszyński, M. (2012). Transformacja systemowa wschodnich Niemiec w perspektywie „cudu gospodarczego" Ludwiga Erharda. Toruń: UMK.

Sinn, G., \& Sinn, H.W. (1991). Kaltstart-volkswirtschaftliche Aspekte der deutschen Vereinigung. Tuebingen: J.C.B. Mohr (Paul Siebeck).

Thieme, M.J. (1995). Spoteczna gospodarka rynkowa. Warszawa: Wydawnictwo C.H. Beck.

Tomala, M. (1979). Gospodarka RFN wczoraj, dziś i jutro. Warszawa: Państwowe Wydawnictwo Ekonomiczne.

Wagner, A. (1972). Die Wachstumszyklen in der Bundesrepublik Deutschland. Eine komparativ-dynamische Komponentenanalyse fuer die Jahre 1951-1970. Tuebingen: J.C.B. Mohr (Paul Siebeck).

Wallich, H.C. (1955). Triebkräfte des deutschen Wiederaufstiegs. Frankfurt/Main: Fritz Knapp.

Wawro, J. (2012). Spoteczna gospodarka rynkowa. Recepta na kryzys. Jarosław-Rzeszów: Galicea Publishers.

Wielka historia świata. Vol. 11 (2006). Kraków: Fogra Oficyna Wydawnicza. 